\title{
Communication
}

\section{Selective oxidation of toluene using surface-modified vanadium oxide nanobelts}

\author{
LI Xuan †, YE Shuang †, ZHAO Jianbo, LI Lei, PENG Luming, DING Weiping* \\ Key Laboratory of Mesoscopic Chemistry of MOE, School of Chemistry and Chemical Engineering, Nanjing University, Nanjing 210093, Jiangsu, China
}

\section{A R T I C L E I N F O}

Article history:

Received 30 April 2013

Accepted 15 May 2013

Published 20 July 2013

Keywords:

Vanadium oxide nanobelt

Selective oxidation

Toluene

Hexadecylphosphonic acid

Surface modification

\begin{abstract}
A B S T R A C T
Vanadium oxide nanobelts were synthesized using a sonochemical-hydrothermal method. Hexadecylphosphonic acid (HDPA) was introduced onto the surfaces of the nanobelts and bulk vanadium oxide to tune their catalytic properties; these properties were tested using gas-phase oxidation of toluene. The catalytic activity of the vanadium oxide nanobelts was higher than that of the bulk oxide as a result of the higher lattice oxygen activity of the nanobelts. Doping with HDPA, tuning the lattice oxygen activity, and blocking unselective sites led to both higher activity and selectivities for benzaldehyde and benzoic acid on nanobelt-like vanadium oxides, whereas led to lower activity but higher selectivities for benzaldehyde and benzoic acid on bulk vanadium oxides.
\end{abstract}

(C) 2013, Dalian Institute of Chemical Physics, Chinese Academy of Sciences. Published by Elsevier B.V. All rights reserved.
Selective oxidation reactions are of great importance in transforming raw materials into intermediates and final products in the chemical industry [1]. The desired products of selective oxidation are usually sensitive to oxidation, which causes low selectivity for desired products [2]. Reactions such as the oxidation of the methyl group in toluene by molecular oxygen to give oxygenates, especially benzaldehyde, remain challenging from both the academic and industrial perspectives. The partial oxidation products of toluene, including benzyl alcohol, benzaldehyde, and benzoic acid, are commercially significant, benzaldehyde being the most valuable among them. In current industrial practice, benzaldehyde is produced via chlorination/hydrolysis of toluene or as a by-product in liquid-phase selective oxidation of toluene to benzoic acid by air [3,4]. However, these processes suffer from environmental problems because they use $\mathrm{Cl}_{2}$ and cause equipment corrosion, and many efforts have been made in recent decades to improve catalytic performance in the heterogeneous oxidation of toluene [3-15].

Vanadium oxide is widely used in such catalytic processes [3,8-14]. The ease of conversion among oxides with different stoichiometries and the formation of oxygen vacancies enables vanadium oxide to function as a catalyst in selective oxidation [16]. Recently, inorganic nanocrystals with well-controlled sizes and shapes have been extensively exploited, and exposed facet-function relationships have been established [17]. Moreover, molecules adsorbed as stabilizers on the nanocrystal surface have been reported to affect the catalytic activity of nanocrystals $[5,18]$. We have reported exclusive selectivity for benzaldehyde in toluene oxidation by molecular oxygen over oleic acid-coated $\mathrm{CeO}_{2}$ nanocubes. This selectivity is believed to be related to surface modification by oleic acid of the well-defined $\mathrm{CeO}_{2}$ nanocubes [5]. Centi and Perathoner [19] have discussed the possibilities of adding various organic additives to the gas phase to improve catalytic performances. Continuously dosing

† LI Xuan and YE Shuang contributed equally.

*Corresponding author. Tel: +86-25-83686219; Fax: +86-25-83686251; E-mail: dingwp@nju.edu.cn

This work was supported by the National Natural Science Foundation of China (21273107).

DOI: 10.1016/S1872-2067(12)60619-6 | http://www.sciencedirect.com/science/journal/18722067 | Chin. J. Catal., Vol. 34, No. 7, July 2013 
the feed with pyridine during the partial oxidation of toluene on vanadium phosphate catalysts leads to significantly increased aldehyde selectivity [20]. It has also been demonstrated that self-assembled monolayers of alkylphosphonic acids on metal oxides can protect the metal from corrosion as a result of the strong chelation properties of alkylphosphonic acids [21], and nanostructured vanadium oxide exhibited unique catalytic properties in butane oxidation [22].

In this paper, we report an investigation of the surface modification of vanadium oxides by $n$-hexadecylphosphonic acid (HDPA) for the selective oxidation of toluene. Vanadium oxide nanobelts showed enhanced catalytic activity for toluene oxidation, and surface modification by HDPA increased the selectivity for partial oxidation products.

$\mathrm{V}_{2} \mathrm{O}_{5}$ nanobelts were prepared using a simple sonochemical-hydrothermal method. Bulk $\mathrm{V}_{2} \mathrm{O}_{5}$ and $\mathrm{NaNO}_{3}$ were mixed in deionized water in a molar ratio of 1:1 and exposed to ultrasonic irradiation with a power of $400 \mathrm{~W} / \mathrm{cm}^{2}$. The mixture was then placed in a Teflon-lined autoclave at $453 \mathrm{~K}$ for $24 \mathrm{~h}$. The resulting precipitates were thoroughly washed and dried at $333 \mathrm{~K}$ for $12 \mathrm{~h}$. The solid was collected and designated as $\mathrm{V}_{2} \mathrm{O}_{5}$ nanobelts. Surface modification of the $\mathrm{V}_{2} \mathrm{O}_{5}$ nanobelts was carried out by immersing a sample in an ethanol solution of HDPA, with stirring, for $2 \mathrm{~h}$. The solvent was removed then in an oven at $353 \mathrm{~K}$. The sample with HDPA was designated as $\mathrm{HDPA} / \mathrm{V}_{2} \mathrm{O}_{5}$ nanobelts (the HDPA surface density was about two molecules per $\mathrm{nm}^{2}$ of $\mathrm{V}_{2} \mathrm{O}_{5}$ nanobelt surface). Bulk $\mathrm{V}_{2} \mathrm{O}_{5}$ and HDPA were mixed in deionized water in a molar ratio of 20:1 and exposed to ultrasonic irradiation with a power of $400 \mathrm{~W} / \mathrm{cm}^{2}$. The mixture was placed in a Teflon-lined autoclave at $453 \mathrm{~K}$ for $24 \mathrm{~h}$. This sample was designated as $\mathrm{V}_{2} \mathrm{O}_{5} @ H D P A$ (the HDPA surface density was about 10 molecules per $\mathrm{nm}^{2}$ of bulk $\mathrm{V}_{2} \mathrm{O}_{5}$ surface).

$\mathrm{X}$-ray diffraction $(\mathrm{XRD})$ patterns were obtained with a Phillips X'Pro diffractometer using $\mathrm{Cu} K_{\alpha}$ radiation $(\lambda=0.15418$ $\mathrm{nm}$ ) at $40 \mathrm{kV}$ and $25 \mathrm{~mA}$. Fourier-transform infrared (FT-IR) spectra of the samples were obtained with a Bruker Vertex 70 spectrometer using $\mathrm{KBr}$ pellets; 64 scans were recorded, with a resolution of $4 \mathrm{~cm}^{-1}$. The specific surface area was determined from $\mathrm{N}_{2}$ adsorption at $77 \mathrm{~K}$, using the BET method, on a Micromeritics ASAP-3020 instrument. $\mathrm{H}_{2}$ temperature-programmed reduction ( $\mathrm{H}_{2}$-TPR) was performed using a TP-5080 adsorption instrument. A mixture of $\mathrm{Ar}$ and $4 \% \mathrm{H}_{2}$ was used and the flow rate was maintained at $20 \mathrm{ml} / \mathrm{min}$. The $\mathrm{H}_{2}$ consumption was monitored using a thermal conductivity detector (TCD), and the calibration of the TCD was performed by reducing a known amount of $\mathrm{CuO}$ to $\mathrm{Cu}^{0}$. Temperature-programmed desorption of $\mathrm{NH}_{3}\left(\mathrm{NH}_{3}\right.$-TPD) was carried out by monitoring the $\mathrm{NH}_{3}$ desorbed from the sample in a He flow of $31.8 \mathrm{ml} / \mathrm{min}$, using a TCD. The samples were pretreated with $\mathrm{He}$ at $573 \mathrm{~K}$ and $\mathrm{NH}_{3}$ was pre-adsorbed at $473 \mathrm{~K}$. Transmission electron microscopy (TEM) measurements were conducted using a JEOL JEM-200CX instrument at an accelerating voltage of $200 \mathrm{kV}$. Field-emission scanning electron microscopy (FE-SEM) was performed using a Hitachi FE-SEM S4800.

In the toluene oxidation reaction, $200 \mathrm{mg}$ of catalyst were introduced into a tubular quartz fixed-bed microreactor. The reaction gases were $\mathrm{O}_{2}$ and $\mathrm{N}_{2}$ at flow rates of $20 \mathrm{ml} / \mathrm{min}$. Toluene was fed into the $\mathrm{O}_{2}$ and $\mathrm{N}_{2}$ gases using a TJ-1A syringe pump controller; the toluene: $\mathrm{O}_{2}: \mathrm{N}_{2}$ molar ratio was kept as 0.8:20:80. The gaseous products were analyzed online using a GC-9800 gas chromatograph equipped with a packed column. The organic products were collected at $273 \mathrm{~K}$ in anhydrous ethanol, and then analyzed using a Shimadzu GC-2014 gas chromatograph. When changing from a given experimental condition to another, a period of $1 \mathrm{~h}$ was allowed for reaching a new steady-state. At each temperature point, the reaction results were recorded for $4 \mathrm{~h}$. $\mathrm{CO}, \mathrm{CO}_{2}$, benzaldehyde, benzoic acid, maleic anhydride, and phthalic anhydride were the main reaction products. The gas-phase products and organic products were quantitatively measured using relative correction factors and using $p$-xylene as an internal standard, respectively. The conversion was defined as the ratio of the number of moles of toluene converted to the number of moles of toluene fed into the reactor. The product selectivity was calculated on the basis of converted toluene.

Figure 1 (a) shows typical SEM and TEM images of $\mathrm{V}_{2} \mathrm{O}_{5}$ nanobelts synthesized using a simple sonochemical-hydrothermal method. The products have belt-like nanostructures with typical lengths of up to several micrometers. The widths and thicknesses of the nanobelts are in the ranges $50-100$ and $20-50 \mathrm{~nm}$, respectively. Figure 1 (b) shows that surface modification with HDPA does not change the morphology of the $\mathrm{V}_{2} \mathrm{O}_{5}$ nanobelts.

Figure 1(c) and 1(d) show typical electron microscopy images of the samples after the toluene oxidation reaction. The $\mathrm{V}_{2} \mathrm{O}_{5}$ nanobelts appear to be sintered to some extent during the reaction, but the morphologies of the HDPA/ $\mathrm{V}_{2} \mathrm{O}_{5}$ nanobelts are basically one-dimensional structures after the toluene reaction. This implies protection by the deposition and adsorption of HDPA of the $\mathrm{V}_{2} \mathrm{O}_{5}$ nanobelts from sintering, possibly because adsorption of HDPA passivates the over-active sites on the $\mathrm{V}_{2} \mathrm{O}_{5}$ nanobelts, for example the peaks and edges. Because of the adsorption of HDPA molecules on the oxide surfaces, the specific areas of the HDPA-surface-modified catalysts cannot be
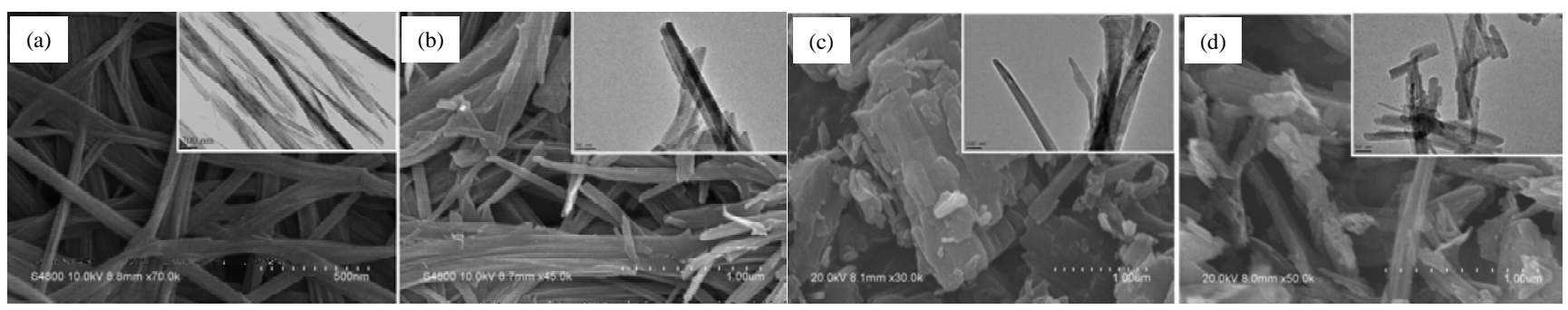

Fig. 1. SEM and TEM (inset) images of $\mathrm{V}_{2} \mathrm{O}_{5}$ nanobelts $(\mathrm{a}, \mathrm{c})$ and $\mathrm{HDPA} / \mathrm{V}_{2} \mathrm{O}_{5}$ nanobelts $(b, d)$ before $(\mathrm{a}, \mathrm{b})$ and after (c, d) reaction. 


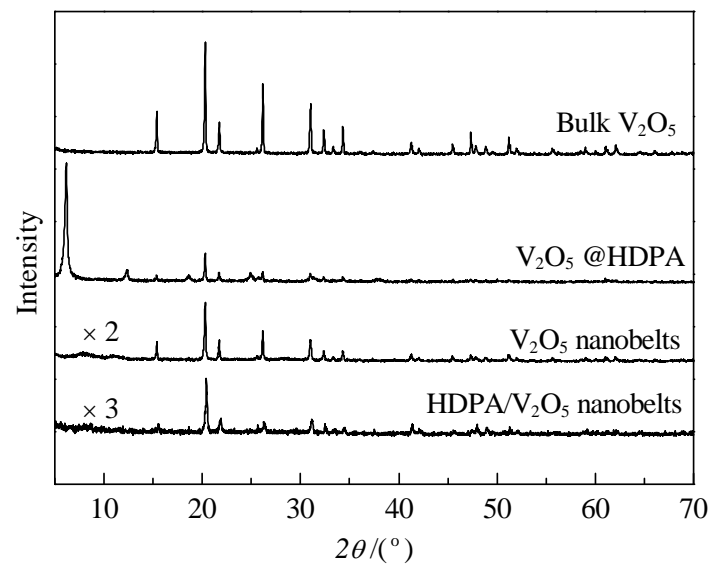

Fig. 2. XRD patterns of different catalysts.

accurately determined; however, it is speculated that the specific areas of the HDPA-modified samples are about the same as that of the corresponding pure vanadium oxide, based on the electron microscopy images.

Figure 2 shows the XRD patterns of the catalysts; all the peaks are indexed to the $\mathrm{V}_{2} \mathrm{O}_{5}$ phase. The peaks at $6.2^{\circ}$ and $12.3^{\circ}$ in the $\mathrm{V}_{2} \mathrm{O}_{5} @$ HDPA sample may be caused by intercalation of HDPA molecules into the lamellar structure of $\mathrm{V}_{2} \mathrm{O}_{5}$, similar to the intercalation of $\mathrm{VOPO}_{4} \cdot 2 \mathrm{H}_{2} \mathrm{O}$ with 1-butanol [23]. However, there are more HDPA molecules on the $\mathrm{V}_{2} \mathrm{O}_{5}$ surface, as shown by the FT-IR spectra.

Figure 3(a) presents the FT-IR spectra of the catalysts from 3100 to $2700 \mathrm{~cm}^{-1}$. The peaks at 2918 and $2850 \mathrm{~cm}^{-1}$ for the HDPA-modified $\mathrm{V}_{2} \mathrm{O}_{5}$ originate from methylene asymmetric and symmetric stretching modes, respectively [21]. This result indicates adsorption of HDPA on the $\mathrm{V}_{2} \mathrm{O}_{5}$ surface. Figure 3(b) shows IR peaks at 2929 and $2856 \mathrm{~cm}^{-1}$ from the used HDPA $/ \mathrm{V}_{2} \mathrm{O}_{5}$ nanobelts and peaks at 2920 and $2850 \mathrm{~cm}^{-1}$ from the used $\mathrm{V}_{2} \mathrm{O}_{5} @ \mathrm{HDPA}$, indicating that the HDPA adsorbed on the catalyst surfaces is stable to some extent during the reaction. Thermogravimetric analysis (results not shown here) shows that approximately $60 \%$ of the HDPA molecules are de-
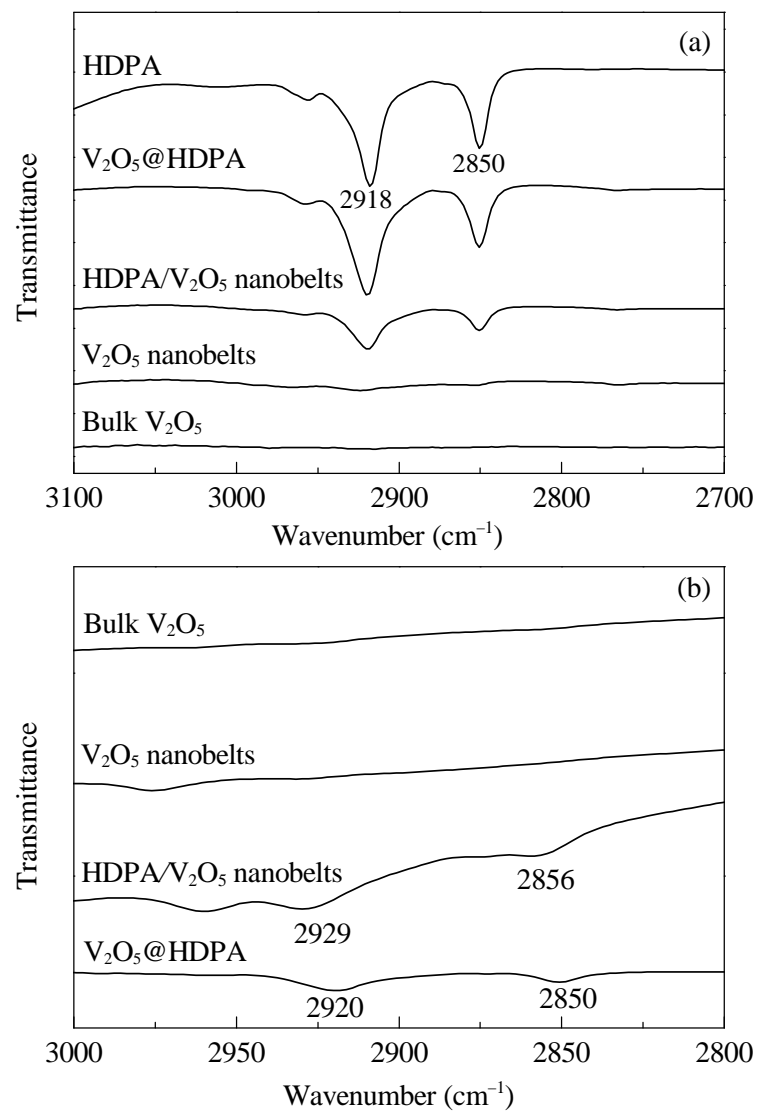

Fig. 3. FT-IR spectra of different samples before (a) and after (b) reaction.

sorbed or decomposed after treatment up to $800 \mathrm{~K}$ in $\mathrm{N}_{2}$. Because these catalysts are used at about $200 \mathrm{~K}$ below this temperature, it is assumed that a smaller amount of HDPA molecules will be desorbed or decomposed during the reaction.

Figure 4(a) shows the $\mathrm{H}_{2}$-TPR profiles of the catalysts. The two peaks at 927 and $951 \mathrm{~K}$ for bulk $\mathrm{V}_{2} \mathrm{O}_{5}$ can be ascribed to the reduction of $\mathrm{V}_{2} \mathrm{O}_{5}$ to $\mathrm{V}_{6} \mathrm{O}_{13}$ and reduction of $\mathrm{V}_{6} \mathrm{O}_{13}$ to $\mathrm{VO}_{2}$, respectively [24]. Interestingly, a peak at $760 \mathrm{~K}$ emerged for the
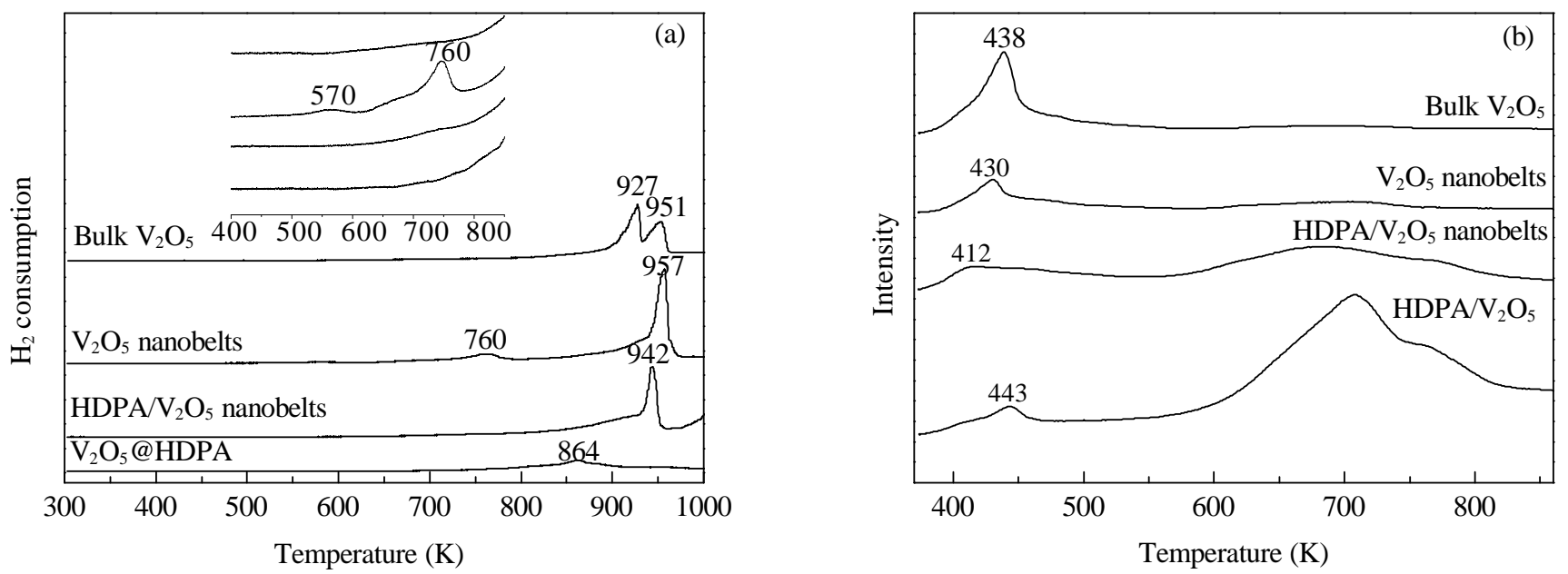

Fig. 4. $\mathrm{H}_{2}$-TPR (a) and $\mathrm{NH}_{3}$-TPD (b) profiles of different catalysts. The inset is a magnified profile between 400 and $850 \mathrm{~K}$. 
$\mathrm{V}_{2} \mathrm{O}_{5}$ nanobelt sample. Quantitative calculations for this peak show that approximately $1.5 \%$ of the oxygen atoms in the $\mathrm{V}_{2} \mathrm{O}_{5}$ nanobelts were consumed in this step. From the inset in Fig. $4(\mathrm{a})$, it can be seen that the lattice oxygen starts to be active at $400 \mathrm{~K}$ and forms a small peak at $570 \mathrm{~K}$. We tentatively ascribe these more-active oxygen species to those located at the acme and edge areas of the nanobelts, which are commonly believed to be more active in reactions. Surface modification of the $\mathrm{V}_{2} \mathrm{O}_{5}$ nanobelts with HDPA led to the disappearance of the peaks at 760 and $570 \mathrm{~K}$. This might arise from strong chelation of $\mathrm{PO}(\mathrm{OH})_{2}$ groups with active unsaturated vanadium sites on the acmes and edges of the nanobelts. This result indicates that HDPA adsorbed on the surface of $\mathrm{V}_{2} \mathrm{O}_{5}$ nanobelts can stabilize the extremely active lattice oxygens. The lattice oxygen reactivity of $\mathrm{V}_{2} \mathrm{O}_{5} @ \mathrm{HDPA}$ is significantly lower than that of bulk $\mathrm{V}_{2} \mathrm{O}_{5}$. The activity of the oxides can be controlled by adjusting the amount of HDPA adsorbed.

Figure 4(b) shows the $\mathrm{NH}_{3}$-TPD profiles of the catalysts. In $\mathrm{NH}_{3}$-TPD measurements, the temperature of the maximum $\mathrm{NH}_{3}$ desorption normally reflects the relative strengths of the acid sites, and the area of the $\mathrm{NH}_{3}$ desorption peak reflects the number of acid sites [25]. The bulk $\mathrm{V}_{2} \mathrm{O}_{5}$ exhibited a peak centered at $438 \mathrm{~K}$; the $\mathrm{V}_{2} \mathrm{O}_{5}$ nanobelts had same acidity but a much smaller number of acid sites. Modification of the $\mathrm{V}_{2} \mathrm{O}_{5}$ nanobelt surfaces with HDPA caused $\mathrm{NH}_{3}$ desorption at lower temperatures with reduced peak areas, which means both weaker acidity and fewer acid sites. The broad band from 556 to $827 \mathrm{~K}$ is probably the result of desorption or decomposition of HDPA on the oxide surface; this can also be seen for the $\mathrm{V}_{2} \mathrm{O}_{5} @ \mathrm{HDPA}$ sample. The larger area of this broad band in the latter sample might be the result of a higher HDPA surface modification density. The HDPA/ $/ \mathrm{V}_{2} \mathrm{O}_{5}$ nanobelts had a higher acid site density than pure oxide nanobelts did, possibly as a result of over-doping by $\mathrm{PO}(\mathrm{OH})_{2}$ groups in HDPA onto the $\mathrm{V}_{2} \mathrm{O}_{5}$ nanobelt surfaces. Toluene and benzaldehyde have been reported to be strongly adsorbed on acid sites, leading to complete oxida-

\section{Table 1}

Catalytic properties of catalysts at different temperatures in toluene oxidation.

\begin{tabular}{lccrrrrr}
\hline \multirow{2}{*}{ Catalyst } & $\begin{array}{c}A_{\text {BET }} \\
\left(\mathrm{m}^{2} / \mathrm{g}\right)\end{array}$ & $T / \mathrm{K}$ & $\begin{array}{c}\text { Conver- } \\
\text { sion }(\%)\end{array}$ & \multicolumn{4}{c}{ Selectivity $(\%)$} \\
\hline Bulk $\mathrm{V}_{2} \mathrm{O}_{5}$ & 16 & 573 & 6.3 & 72.8 & 67.7 & 5.1 & 14.4 \\
& & 593 & 11.6 & 69.6 & 58.2 & 11.4 & 14.7 \\
& & 613 & 22.7 & 60.7 & 45.7 & 15.1 & 23.5 \\
& & 633 & 58.3 & 58.9 & 40.0 & 18.9 & 29.8 \\
$\mathrm{~V}_{2} \mathrm{O}_{5}$ nanobelts & 20 & 553 & 8.8 & 75.3 & 60.9 & 14.4 & 8.9 \\
& & 573 & 10.3 & 64.6 & 46.6 & 17.9 & 18.9 \\
& & 593 & 20.1 & 51.9 & 27.5 & 24.4 & 29.2 \\
& & 613 & 33.6 & 49.1 & 25.5 & 23.7 & 33.8 \\
$\mathrm{HDPA} / \mathrm{V}_{2} \mathrm{O}_{5}$ & - & 553 & 9.2 & 63.2 & 41.9 & 21.3 & 12.1 \\
nanobelts & & 573 & 25.2 & 59.8 & 28.2 & 31.6 & 22.9 \\
& & 593 & 35.6 & 58.8 & 21.0 & 37.8 & 29.0 \\
& & 613 & 89.0 & 5.5 & 2.1 & 3.3 & 89.1 \\
$\mathrm{~V}_{2} \mathrm{O}_{5} @ \mathrm{HDPA}$ & - & 593 & 2.7 & 81.4 & 81.4 & 0 & 8.7 \\
& & 613 & 7.6 & 79.7 & 76.2 & 3.5 & 12.5 \\
& & 633 & 14.1 & 73.3 & 65.1 & 7.2 & 16.8 \\
& & 653 & 27.3 & 64.6 & 54.8 & 9.8 & 24.2 \\
\hline
\end{tabular}

Reaction conditions: catalyst $0.2 \mathrm{~g}$, toluene $0.8 \%(\mathrm{v}), \mathrm{O}_{2} 20 \%(\mathrm{v}), \mathrm{N}_{2}$ $79.2 \%(\mathrm{v}), 20 \mathrm{ml} / \mathrm{min}$

BA: benzaldehyde; BAc: benzoic acid; $\mathrm{CO}_{x}: \mathrm{CO}$ and $\mathrm{CO}_{2}$. tion to $\mathrm{CO}_{x}[8,20]$. The effects on toluene oxidation of the surface acidities of the catalysts synthesized in this study will be discussed below.

Table 1 lists the effects of temperature on toluene oxidation over different catalysts. The conversion of toluene and selectivity for benzoic acid (BAc) increase with increasing temperature, whereas the selectivity for benzaldehyde (BA) decreases, in accordance with previous results $[12,13] . \mathrm{V}_{2} \mathrm{O}_{5} @ H D P A$ gives better selectivity for benzaldehyde but the lowest conversion of toluene at all tested temperatures.

At $573 \mathrm{~K}$, the conversion of toluene is low (6.3\%), with $67.7 \%$ and $5.1 \%$ selectivities for benzaldehyde and benzoic acid, respectively, over bulk $\mathrm{V}_{2} \mathrm{O}_{5} . \mathrm{V}_{2} \mathrm{O}_{5}$ nanobelts show slightly higher activity than the bulk oxide does, with a toluene conversion of $10.3 \%$. However, the selectivity for benzaldehyde drops to $46.6 \%$, and the selectivity for benzoic acid increases to $17.9 \%$. It has been proven that the Mars-van Krevelen mechanism applies to gas-phase oxidation of toluene by vanadium oxide, so the main active oxygen species should be lattice oxygen $[9,13,14,26]$. The above-mentioned differences between the catalytic performance of bulk $\mathrm{V}_{2} \mathrm{O}_{5}$ and $\mathrm{V}_{2} \mathrm{O}_{5}$ nanobelts can therefore be explained by the higher lattice oxygen activity of the latter, which was shown by $\mathrm{H}_{2}$-TPR (Fig. 4(a)). Surface modification of $\mathrm{V}_{2} \mathrm{O}_{5}$ nanobelts with HDPA (HDPA/ $\mathrm{V}_{2} \mathrm{O}_{5}$ nanobelts) greatly increases the toluene conversion from $10.3 \%$ to $25.2 \%$ at $573 \mathrm{~K}$. More importantly, the selectivity for $\mathrm{CO}_{x}$ remains at $22.9 \%$. The lower tendency to produce total oxidation products on the HDPA $/ \mathrm{V}_{2} \mathrm{O}_{5}$ nanobelts might be associated with the disappearance of the low-temperature peak in the $\mathrm{H}_{2}$-TPR results. As discussed above, these low-temperature peaks may correspond to highly reactive lattice oxygens, which might over-oxidize toluene to $\mathrm{CO}_{x}$. Eliminating these highly active lattice oxygen species by HDPA surface modification therefore greatly suppresses total oxidation. Moreover, $\mathrm{V}_{2} \mathrm{O}_{5} @ \mathrm{HDPA}$ exhibits a much lower activity but higher selectivity for benzaldehyde, and has the highest selectivity for $\mathrm{C}_{7}$ compounds. Also, surface modification of $\mathrm{V}_{2} \mathrm{O}_{5}$ nanobelts by HDPA gives higher selectivity for $\mathrm{C}_{7}$ compounds when the toluene conversion exceeds $20 \%$.

From Fig. 5, it can be seen that a low HDPA surface modification density on a nanobelt-like oxide leads to higher activity, whereas a higher modification density on the bulk oxide gives

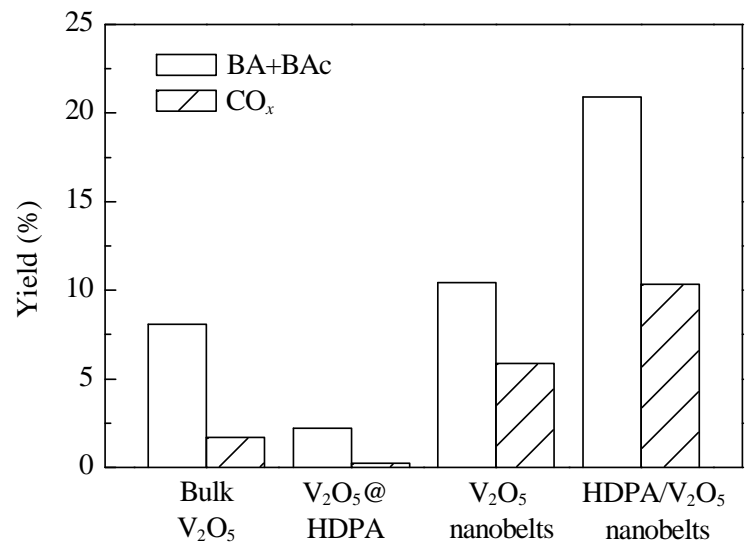

Fig. 5. Catalytic performance of catalysts at $593 \mathrm{~K}$. 
rise to lower activity at $593 \mathrm{~K}$. This indicates that the peaks centered at around $950 \mathrm{~K}$ in the $\mathrm{H}_{2}$-TPR profile might be the main active oxygen species in the toluene oxidation reaction, because the $\mathrm{V}_{2} \mathrm{O}_{5} @ \mathrm{HDPA}$ sample has the smallest area for this peak. The enhancing effect of HDPA modification of the nanobelts might therefore stem from tuning of the lattice oxygen activity as well as of the surface acidity. The slightly lower temperature peak at $942 \mathrm{~K}\left(15 \mathrm{~K}\right.$ lower than for pure $\mathrm{V}_{2} \mathrm{O}_{5}$ nanobelts) in the TPR profile of HDPA-modified nanobelts may account for the increased activity, and the disappearance of the $760 \mathrm{~K}$ peak as well as of the active lattice oxygen species below this temperature may be the reason for the increased selectivities for benzaldehyde and benzoic acid, because these highly active oxygen species might be too reactive to control the reaction selectivity. Also, the lower $\mathrm{NH}_{3}$ desorption temperature of $412 \mathrm{~K}\left(18 \mathrm{~K}\right.$ lower than that for pure $\mathrm{V}_{2} \mathrm{O}_{5}$ nanobelts) might suggest easier desorption of reaction intermediates because strong acid sites adsorb benzaldehyde more strongly $[8,20]$.

$\mathrm{V}_{2} \mathrm{O}_{5}$ nanobelts were synthesized using a two-step sonochemical-hydrothermal method. Nanostructured vanadium oxide has more-active oxygen species than the bulk oxide, leading to more total oxidation products. The surface adsorption of HDPA on $\mathrm{V}_{2} \mathrm{O}_{5}$ nanobelts significantly modifies their surface acidity and lattice oxygen activity at low temperatures. Their activity for total oxidation of toluene is suppressed and the selectivities for useful products are enhanced. The modification effects of surface adsorbents on the catalytic properties of nanostructured materials are useful for designing new catalysts and processes.

\section{References}

[1] Sheldon R A, Kochi J K. Metal-Catalyzed Oxidations of Organic Compounds. New York: Academic Press, 1981. 26

[2] Hermans I, Spier E S, Neuenschwander U, Turrà N, Baiker A. Top
Catal, 2009, 52: 1162

[3] Xue M W, Yu J N, Chen H, Shen J Y. Catal Lett, 2009, 128: 373

[4] Zhang Z, Gao J, Ma H, Xu J. Chin J Catal (张展, 高进, 马红, 徐杰. 催 化学报), 2012, 33: 1198

[5] Lü J G., Shen Y, Peng L M, Guo X F, Ding W P. Chem Commun, 2010, 46: 5909

[6] Kesavan L, Tiruvalam R, Ab Rahim M H, bin Saiman M I, Enache D I, Jenkins R L, Dimitratos N, Lopez-Sanchez J A, Taylor S H, Knight D W, Kiely C J, Hutchings G J. Science, 2011, 331: 195

[7] Konietzni F, Kolb U, Dingerdissen U, Maier W F. J Catal, 1998, 176: 527

[8] Bulushev D A, Kiwi-Minsker L, Zaikovskii V I, Lapina O B, Ivanov A A, Reshetnikov S I, Renken A. Appl Catal A, 2000, 202: 243

[9] Konietzni F, Zanthoff H W, Maier W F. J Catal, 1999, 188: 154

[10] Bulushev D A, Kiwi-Minsker L, Renken A. Catal Today, 2000, 57: 231

[11] Zhang H L, Zhong W, Duan X, Fu X C. J Catal, 1991, 129: 426

[12] Xue M W, Ge J Z, Zhang H L, Shen J Y. Appl Catal A, 2007, 330: 117

[13] Ponzi M, Duschatzky C, Carrascull A, Ponzi E. Appl Catal A, 1998, 169: 373

[14] Ge H, Chen G W, Yuan Q, Li H Q. Chem Eng J, 2007, 127: 39

[15] Kuang W X, Fan Y N, Chen K D, Chen Y.J Catal, 1999, 186: 310

[16] Haber J. Catal Today, 2009, 142: 100

[17] Zhou K B, Li Y D. Angew Chem, Int Ed, 2012, 51: 602

[18] Narayanan R, El-Sayed M A. J Phys Chem B, 2005, 109: 12663

[19] Centi G, Perathoner S. Catal Today, 1998, 41: 457

[20] Martin A, Bentrup U, Lücke B, Brückner A. Chem Commun, 1999: 1169

[21] Gao W, Dickinson L, Grozinger C, Morin F G, Reven L. Langmuir, 1996, 12: 6429

[22] Taufiq-Yap Y H, Wong Y C, Zainal Z, Hussein M Z. J Nat Gas Chem, 2009, 18: 312

[23] Yamamoto N, Hiyoshi N, Okuhara T. Chem Mater, 2002, 14: 3882

[24] Besselmann S, Freitag C, Hinrichsen O, Muhler M. Phys Chem Chem Phys, 2001, 3: 4633

[25] Due-Hansen J, Kustov A L, Rasmussen S B, Fehrmann R, Christensen C H. Appl Catal B, 2006, 66: 161

[26] Mars P, van Krevelen D W. Chem Eng Sci, 1954, 3(supple 1): 41

\section{Graphical Abstract}

Chin. J. Catal., 2013, 34: 1297-1302 doi: 10.1016/S1872-2067(12)60619-6

Selective oxidation of toluene by surface-modified vanadium oxide nanobelts

LI Xuan, YE Shuang, ZHAO Jianbo, LI Lei, PENG Luming, DING Weiping*

Nanjing University
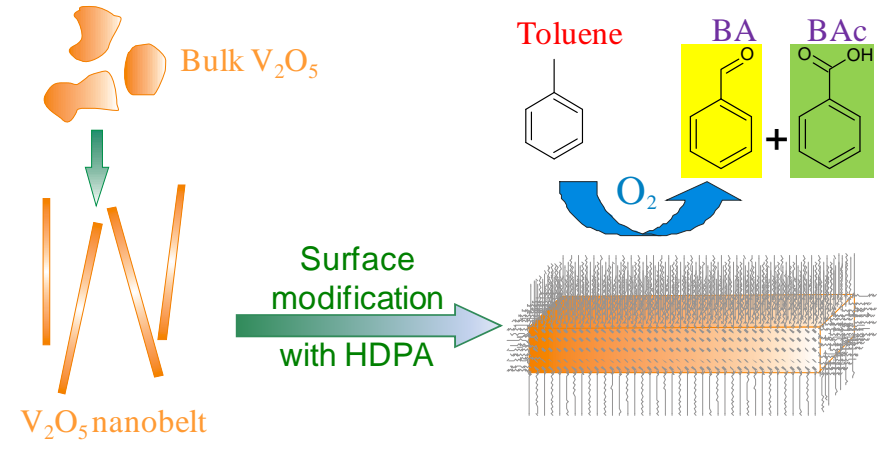

Surface modification with HDPA
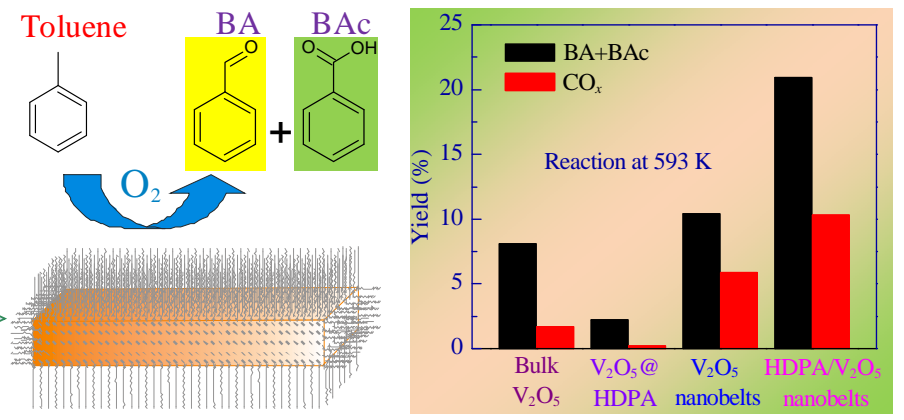

Vanadium oxide nanobelts are more active, but less selective, in toluene oxidation than bulk vanadium oxide is. Significant modification of the selective oxidation of toluene on vanadium oxide nanobelts is achieved by doping with hexadecylphosphonic acid. 


\title{
表面修饰的钒氧化物纳米带上甲苯选择氧化反应
}

\author{
李 轩 ${ }^{\dagger}$, 叶 霜 ${ }^{\dagger}$, 赵建波, 李 䂞, 彭路明, 丁维平 ${ }^{*}$ \\ 南京大学化学化工学院, 介观化学教育部重点实验室, 江苏南京210093
}

摘要: 采用声化学水热法制备了 $\mathrm{V}_{2} \mathrm{O}_{5}$ 纳米带, 并将十六烷基膦酸负载在它和块状 $\mathrm{V}_{2} \mathrm{O}_{5}$ 表面上, 以修饰催化剂表面, 通过调变催化 剂中晶格氧活动性以及表面酸碱性来控制其催化甲苯氧化产物的选择性. 结果表明, $\mathrm{V}_{2} \mathrm{O}_{5}$ 纳米带具有较强的晶格氧活动性, 与普 通块状 $\mathrm{V}_{2} \mathrm{O}_{5}$ 相比, 甲苯转化率更高, 但苯甲醛和苯甲酸的总选择性下降. 经过表面修饰后, $\mathrm{V}_{2} \mathrm{O}_{5}$ 纳米带的催化活性以及苯甲醛、苯 甲酸总选择性增加; 而块状 $\mathrm{V}_{2} \mathrm{O}_{5}$ 上苯甲醛、苯甲酸总选择性更高, 但催化活性显著下降.

关键词: 五氧化二钒纳米带; 选择氧化; 甲苯; 十六烷基膦酸; 表面修饰

收稿日期: 2013-04-30. 接受日期: 2013-05-15. 出版日期: 2013-07-20.

†李轩和叶霜为并列第一作者.

*通讯联系人. 电话: (025)83686219; 传真: (025)83686251; 电子信箱: dingwp@nju.edu.cn

基金来源：国家自然科学基金(21273107).

本文的英文电子版由Elsevier出版社在ScienceDirect上出版(http://www.sciencedirect.com/science/journal/18722067). 